\title{
VALUE CHAIN ANALYSIS OF HONEY IN BANGLADESH: PRODUCTION PRACTICES AND LIVELIHOOD PERSPECTIVE
}

\author{
M.T. Uddin", M.Z.I. Kamal and M. Kamruzzaman \\ Department of Agricultural Economics \\ Bangladesh Agricultural University, Gazipur, Bangladesh
}

\begin{abstract}
The study was designed to develop honey value chain through analyzing the production practices and stakeholders' activities as mediated by livelihood strategies. A total of 84 stakeholders were interviewed for data collection. The study depicts that assemble and set up the wooden box with artificial wooden beehives near the fields was the main procedure for honey production. Apis melifera is the major honey bee reared by the beekeepers and the average number of boxes is 50 , harvested honey per box per year is around $35 \mathrm{~kg}$. Profitability analysis shows that honey production was profitable and the benefit-cost ratio is 1.83. Estimates of logit model indicates that age of household head, educational level, farm size, farm income and non-farm income were the significant factors that influence beekeepers' decision for adoption. The study identified six actors in honey value chain and among the actors; processors added the highest value of total value addition. Engagement in different activities of beekeeping had a great impact on their livelihood. SWOT analysis indicates favorable environment as strength, inadequate market infrastructure as weakness, high demand for honey as opportunities, and dominancy of the middlemen as threat, respectively. Lack of credit, lower price of honey as well as lack of storage facilities was the main problems faced by the stakeholders. To overcome the problems moreover to make this business more profitable, the study recommended to form contract based cooperative groups, establish proper storage facilities and provide necessary training by the government and non-government organizations.
\end{abstract}

Keywords: Value chain analysis, Honey, Production practices, Livelihood

*Corresponding Author: tajbau@yahoo.com 


\section{INTRODUCTION}

As an agricultural country, majority of the people in Bangladesh are directly or indirectly involved in wide range of agricultural activities. Agriculture in Bangladesh is commercialized day by day and the farmers are showing interest in producing valuable crops like vegetable, fruit, oilseeds and pulses in parallel with traditional cereal crops. Pollination acts as the key driver for better production of these commercial crops, and the relationship between flowering plants and flower-visiting insects is of great importance in Bangladesh (Amin et al., 2019). Beekeeping is an important sub-sector of agriculture and honey bees are the most crucial pollinator of agricultural crops and more than $80 \%$ of agricultural crops are more or less dependent on bee pollination (Klein et al., 2007).

Beekeeping can play a vital role in sustainable agricultural development as it increases resource without changing environmental balance. As a cottage industry, it is a source of income of the rural people and one of the important components of integrated rural development programmes (Verma, 1990).

Honey production offers useful opportunity for poor and landless farmers to gain income as it requires minimum startup investment; can be carried out in small space close to the house and generally yield profit. Honey production are environmentally friendly activities and it offers benefit in two ways: firstly, increase in the number of managed and feral honey bee colonies increases honey production which can be sold as high value low volume product; secondly bees support and facilitates gene flow system and helps the environment at different tropic level to improve diversity and productivity (ICIMOD, 2015).

Although commercial beekeeping in Bangladesh is still in a rising stage, it is possible to make the honey farming a million-dollar business for the country. It can be an enterprise of possibility for many self-dependent, freedom loving youths and women and such initiative will ultimately contribute to the economic development of our country.

Value chain analysis is a tool to assess the inter-linkage of different actors involved in the production, processing and distribution of a product (Furuholt and Matotay, 2011). According to (Kaplinsky and Morris, 2001), the value chain describes the full range of activities which are required to bring a product or service from conception, through the different phases of production (involving a combination of physical transformation and the input of various producer services), delivery to final consumers, and final disposal after use.

The present study is linked in some extent with other few studies, which are: Bhattarai et al. (2020) conducted a study on value chain analysis of honey bee (Apis mellifera) products in Chitwan, Nepal and found that the producers, collectors, processors cum wholesalers and retailers were the major value chain actors and the marketing margin of wholesalers cum processors found to be highest; Amin et al. 
(2019) studied on apiculture for sustainable agriculture: Bangladesh perspective and reported that for the development of agriculture and rural economy, bee-keeping may play a vital role as one of the economic activities. Moreover, for strengthening highvalue cash crop production, proper pollination could be ensured through apiculture; Shrestha et al. (2017) performed a study on honey value chain analysis: a case study of Gahate village, Lamjung district of Nepal and pointed out that honey value chain is relatively short initiating from producers and ending in consumers and includes actors like input suppliers and service providers, producers, wholesalers, retailers and consumers; and Islam et al. (2015) performed the financial analysis of apiculture profitability in Bangladesh and revealed that Apis mellifera bee species have a higher IRR than Apis cerana for a particular size.

It is evident from the above discussion that research on value chain analysis of honey in Bangladesh is rare and many policy level questions still are remained unanswered. Therefore, this study was designed to support the policy makers to formulate strategic policies for an effective value chain considering production practices and livelihood status of the stakeholders. The current study was aimed to examine the nature and extent of honey production along with profitability. The study also encompassed the factors affecting adoption of honey production along with development of honey value chain map, value addition by different actors and policy options.

\section{MATERIALS AND METHODS}

\section{Study Areas and Sample Size}

Most of the beekeeping approaches has been taken places based on the nectarine sources of flowers and the beekeepers move their hives according to the availability of nectar and pollen sources, is known as migratory beekeeping. Afterwards, Modhupur upazila of Tangail district, Gurudaspur upazila of Natore district and Birol upazila of Dinajpur district were purposively selected as a place of study area. The primary data was collected from a total of 6 input suppliers, 60 beekeepers, 3 processors, 3 traders, 6 retailers and 6 consumers using a structured questionnaire through direct interview. Simple random sampling technique was used to select the respondents. Focus group discussion (FGD) was conducted to collect group information and cross-check the data and information. Besides, secondary information sources in the form of handouts, reports, publications, notifications, etc. having relevance and similarity with this study were also considered.

\section{Analytical framework}

For analyzing the data, a combination of descriptive, mathematical and statistical techniques was used to achieve the objectives and to get the meaningful results. Profitability of honey production from the view point of individual beekeeper was measured in terms of gross return, gross margin, net return and benefit cost ratio (Dilon and Hardaker, 1993). The formulas needed for the calculation of profitability were discussed below: 


$$
\begin{aligned}
& \mathrm{GR}=\mathrm{P} \times \mathrm{Q} ; \mathrm{GM}=\mathrm{GR}-\mathrm{TVC} ; \mathrm{NR}=\mathrm{GR}-(\mathrm{TFC}+\mathrm{TC}) ; \mathrm{BCR}=\mathrm{GR} \div(\mathrm{TFC}+ \\
& \mathrm{TVC})
\end{aligned}
$$

Where,

$\mathrm{GR}=$ Gross return (Tk); $\mathrm{P}=$ Sales price of the product $(\mathrm{Tk}.) ; \mathrm{Q}=$ Yield per 100 box $(\mathrm{Kg}) ; \mathrm{GM}=$ Gross margin (Tk.); TVC = Total variable cost (Tk.); NR = Net return (Tk.); TFC $=$ Total fixed cost $(\mathrm{Tk}$.$) ; and \mathrm{BCR}=$ Benefit cost ratio.

As there was variation in same location among the farmers in terms of adoption of honey production, the following dichotomous logistic regression analysis (i.e., logit model) was used to identify the factors affecting adoption of honey production (Gujarati, 2003):

$\mathrm{K}_{\mathrm{i}}=\ln \left[\mathrm{P}_{\mathrm{i}} \div\left(1-\mathrm{P}_{\mathrm{i}}\right)\right]=\beta_{0}+\beta_{1} \mathrm{X}_{1}+\beta_{2} \mathrm{X}_{2}+\beta_{3} \mathrm{X}_{3}+\beta_{4} \mathrm{X}_{4}+\beta_{5} \mathrm{X}_{5}+\beta_{6} \mathrm{X}_{6}+\mathrm{E}_{\mathrm{i}}$

Where,

$\mathrm{P}_{\mathrm{i}}$ is the probability of adoption and non-adoption of honey production $\left(\mathrm{P}_{\mathrm{i}}=1\right.$ for adoption and $\mathrm{P}_{\mathrm{i}}=0$ for non-adoption); $\mathrm{K}_{\mathrm{i}}=$ Probability of adoption of honey production of $\mathrm{i}^{\text {th }}$ farmer; $\mathrm{X}_{1}=$ Age of household head (years); $\mathrm{X}_{2}=$ Education level of household head (years of schooling); $X_{3}=$ Farm size (ha); $X_{4}=$ Nonfarm income (Tk.); $\mathrm{X}_{5}=$ Training on honey production (days); $\left(\mathrm{P}_{\mathrm{i}}=1\right.$ indicates having training and $\mathrm{P}_{\mathrm{i}}=0$ indicates having no training); $\mathrm{X}_{6}=$ Farm income (Tk.); $\beta_{0}=$ Intercept; $\beta_{1}$ to $\beta_{6}=$ Regression coefficient of the independent variables; and $\mathrm{E}_{\mathrm{i}}=$ Error term.

In order to develop the value chain map of honey, descriptive statistics with the support of flowchart was used. Value addition at different stages of honey marketing by different stakeholders was estimated using the following equations (Acharya and Agarwal, 1987):

Gross margin $=$ Sales price - Production cost/Purchase price;

Value addition $=$ Gross margin - Marketing cost;

Price spread $=$ Retailers' sales price - Farmers' sales price; and

Producers' share to consumers' Tk. $=$ (Farmers' sales price/Retailers' sales price) $\times 100$.

To address the livelihood patterns of the respondents, the sustainable livelihood framework analysis including the asset pentagon (which is composed of five types of capitals namely, human capital, social capital, natural capital, physical capital and financial capital) were followed (DFID, 2000).

To identify the potentials and challenges of honey value chain, SWOT analysis was constructed. SWOT analysis guides to identify the positives and negatives inside of the organization (S-W) and outside of it in the external environment (O-T) (Uddin et al., 2018). 
Finally, to address the problems in relation to production, value addition and marketing of honey, problem facing index (PFI) was calculated using the following formula (Goswami, 2016):

$\mathrm{PFI}=\left(\mathrm{P}_{\mathrm{s}} \times 3\right)+\left(\mathrm{P}_{\mathrm{m}} \times 2\right)+\left(\mathrm{P}_{1} \times 1\right)+\left(\mathrm{P}_{\mathrm{n}} \times 0\right)$

Where,

$\mathrm{P}_{\mathrm{s}}=$ Number of respondents facing the problems severely (weight assigned as $3)$;

$\mathrm{P}_{\mathrm{m}}=$ Number of respondents facing the problems moderately (weight assigned as 2);

$P_{1}=$ Number of respondents facing the problems at low level (weight assigned as 1); and $P_{n}=$ Number of respondents facing no problems (weight assigned as $0)$.

\section{RESULTS AND DISCUSSION}

\section{Socioeconomic status of the respondents}

The socioeconomic status of the respondents represented that average number of members in respondents' family was 5.63, which was almost 1.3 times higher compare to national average of 4.1 (BBS, 2016). It is seen that about $57.4 \%$ beekeepers had crossed above secondary educational level and most of the respondents' $(78.7 \%)$ average years of experience was more than 10 years in honey production. With regard to the number of hives possession, majority of the beekeepers $(57.0 \%)$ owned about 50-100 bee hives. In terms of training, 52.5\% of the beekeepers had no training in related to beekeeping.

\section{Nature and extent of honey production}

Beekeepers generally collected honey from types of honey bees in Bangladesh. The bee species are namely Apis dorsata, Apiscerana, Apisflorea and Apis mellifera. Among the four mentioned bee species, it is seen that beekeepers mainly reared Apis mellifera honey bee for their apiculture activities in the study areas. Beekeepers followed some procedures for completion of these activities. It is found that beekeepers usually selected shady, dry and suitable places near the major nectar producing plants such as mustard, cumin, coriander, litchi, etc., where bees found their adequate food to produce good quality honey. Then, they made wooden box with an average height of 14 inch and width of 10 inch and maintain the distance around 1 feet between two boxes and lastly purchased a nuclear colony having a queen bee, a male bee and workers bees from a local apiary. In the period of honey extraction, they used some instruments such as honey extracting machine, smoker, protective clothes, brush, etc. Beekeepers cleaned up the beehive box once in a week and checked out the presence of queen bee in the box after the extraction of honey. It is seen that each beekeeper harvested about $35 \mathrm{~kg}$ honey from each beehive box in a 
year. The peak season of honey extraction lasts only six months (from November to April) in the study areas.

\section{Profitability of beekeeping}

To determine the sustainability of beekeeping, it is necessary to analyze the profitability. It is apparent from Table 1 that the benefit cost ratio (BCR) was found as 1.83 which revealed that beekeeping was profitable. The current findings are similar with the earlier observations of (Bhattarai et al. 2020), in which the benefit cost ratio was found as to be 1.56 per hive.

Table 1. Profitability of beekeeping

\begin{tabular}{lc}
\hline Items & Amount (Tk./100 Boxes/ Year) \\
\hline Total fixed cost (TFC) & 8000 \\
Total variable cost (TVC) & 675060 \\
Total cost (TC = TFC+TVC) & 683060 \\
Total production (kg) & 5000 \\
Price (Tk./kg) & 250 \\
Gross return (GR) & 1250000 \\
Gross margin (GM = GR-TVC) & 574940 \\
Net return (GR-TC) & 566940 \\
Benefit cost ratio (BCR = GR $\div$ TC) & 1.83 \\
\hline
\end{tabular}

\section{Factors affecting adoption of honey production}

Table 2 presents the result of logit regression model. Six independent variables were identified as major determinants of adopting honey production by the beekeepers which were: age of household head, educational level of household head, farm size, non-farm income, training and farm income.

Table 2. Estimates of logistic regression of determinants of adopting honey production

\begin{tabular}{lcccccc}
\hline \multicolumn{1}{c}{ Variables } & $\begin{array}{c}\text { Coefficient } \\
(\beta)\end{array}$ & $\begin{array}{c}\text { Standard } \\
\text { Error }\end{array}$ & $\mathrm{z}$ & $\mathrm{P}>|\mathrm{z}|$ & \multicolumn{2}{c}{$\begin{array}{c}\text { 95\% Confidence } \\
\text { Interval }\end{array}$} \\
\hline Constant & 5.859 & 2.995 & 1.17 & 0.001 & 1.067 & 5.648 \\
Age of household head $\left(\mathrm{X}_{1}\right)$ & $-0.363^{* * *}$ & 0.123 & -2.95 & 0.003 & -0.605 & -0.121 \\
Educational level of household & $0.068^{*}$ & 0.219 & 0.31 & 0.075 & -0.362 & 0.499 \\
head $\left(\mathrm{X}_{2}\right)$ & & & & & & \\
Farm size $\left(\mathrm{X}_{3}\right)$ & $-5.153^{*}$ & 2.794 & -1.84 & 0.065 & 0.631 & 0.323 \\
Non-farm income $\left(\mathrm{X}_{4}\right)$ & $0.012^{* *}$ & 0.039 & 1.38 & 0.039 & 0.011 & 0.019 \\
Training $\left(\mathrm{X}_{5}\right)$ & 0.147 & 1.185 & 0.12 & 0.901 & -2.176 & 2.470 \\
Farm income $\left(\mathrm{X}_{6}\right)$ & $0.009^{* * *}$ & 0.020 & 2.92 & 0.004 & -0.002 & 0.013 \\
\hline
\end{tabular}

$* * * \mathrm{P}<0.01, * * \mathrm{P}<0.05, * \mathrm{P}<0.1$ 
It is depicted from the Table 2 that the estimated coefficient of educational level of household head, non-farm income and farm income were positive and significant at $10 \%, 5 \%$ and $1 \%$ level, respectively which implies that having higher level of education, more non-farm and farm income had higher probability of adopting honey production in the study area. Besides these factors, experience in beekeeping, apiary size, access to credit would also have significant influence on farmers' decision of adopting honey production (Mujuni et al., 2012).

\section{Actors involved in the honey value chain}

Honey value chain describes the way in which the honey flows from its inception to ultimate users. Figure 1 depicts the activity of various actors' involved in honey value chain.

\section{Input suppliers}

Input suppliers are the basic support service providers in the honey value chain. Input suppliers contribute for the foundation of the value chain and they comprise organizations and or individual entrepreneurs engaged in the construction and supply of beekeeping equipment to interested producers. They mostly focus on producing beehives along with other hive equipments. Inputs for beekeeping include beehive, bee veils, bee colonies, hive stands, gloves, hat, brush, smoker, medicines, supplementary feed (sugar) and honey extractors.

\section{Producers (Beekeepers)}

Producers are the major actors in value chain who aggregate all the required inputs from different possible sources and manage them in an efficient way for high quality and quantity of honey production. It was found that average number of boxes of hive was 50. Apis mellifera is mostly reared and modern beehives have been in practice these days which are found to be more convenient and productive as compared to the traditional ones. About $35 \mathrm{~kg}$ of honey has been extracted at most from each beehive annually. Best quality honey obtained in winter season from mustard field. The peak season of honey growing lasts only six months (November to April). The beekeepers sell honey either directly to the local consumers or to the wholesalers or processors. Commission agents collected honey from the producers directly. There is no provision of grading, processing and labeling of the product at producer's point.

\section{Processors}

These are actors who collect crude honey at a farm get level from the producers then adding value through processing and supply honey to the commission agent and company.

\section{Companies}

Around twenty local brands of honey are sold in the domestic market of Bangladesh. From these, Ayurvedia Pharma (AP Honey), Lichi Honey, Tropica Honey, Pran, Bengal Honey, Moti Modhu, Nahol Honey, Amber Honey, etc. are more popular brand. Various foreign brands of honey are also sold in the market of Bangladesh. 


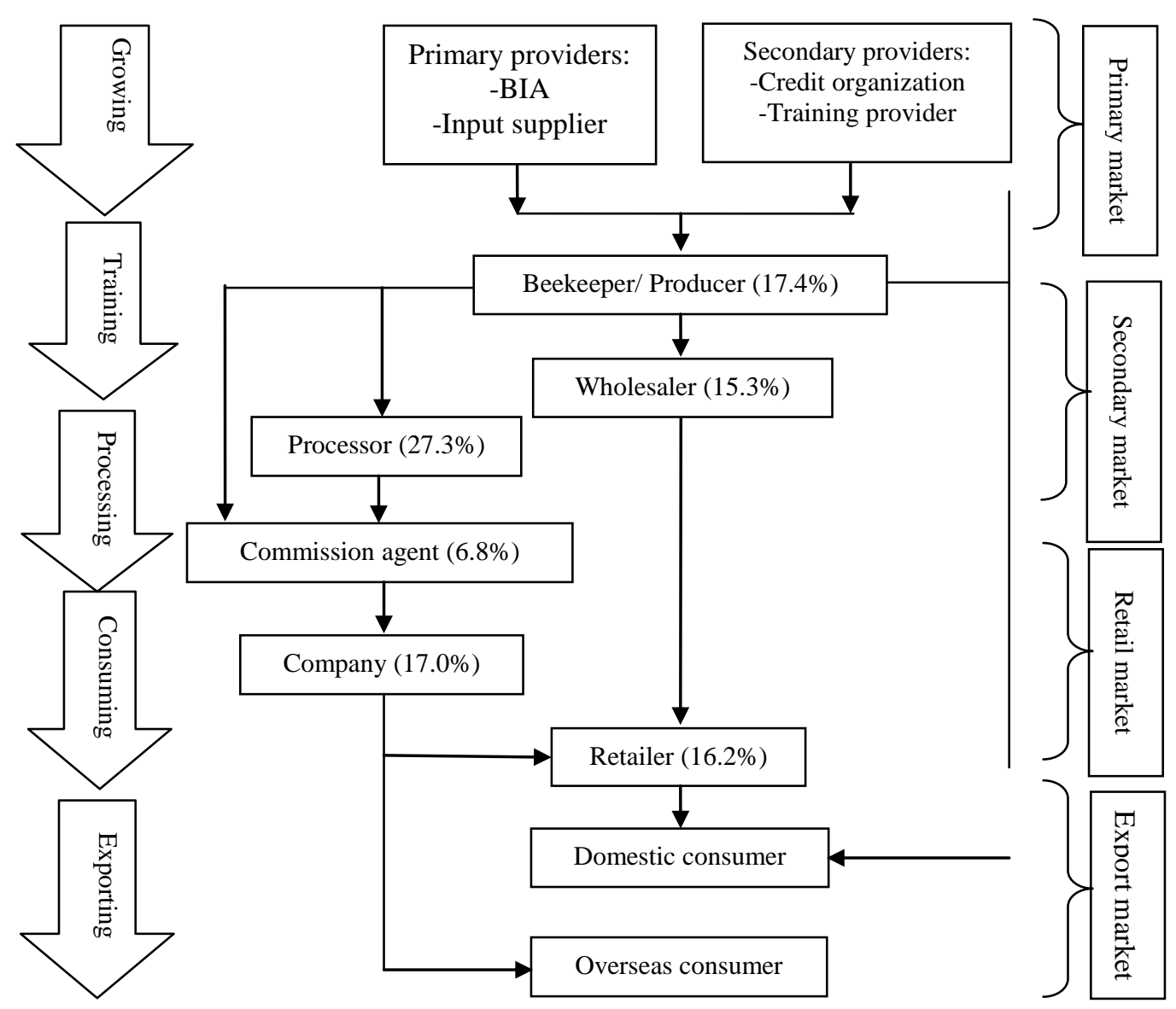

Figure 1. Value chain map of honey

Note: Values within the parentheses indicate percentage of the total value addition.

\section{Wholesalers}

These actors buy honey from producers at a large quantity and resell to other traders in a bulk. They contact with their regular producers and demand for the product. In most cases, they visit the producers themselves at the production site to buy honey. The wholesalers either sell honey directly to the consumers after packaging or they supply honey to retail shops and supermarkets after packaging. They have also storage facilities for storing the packed honey. Payment to producers is done through cash during the time of their visit.

\section{Retailers}

Retailers are the value chain actors who buy the products from wholesalers or companies and sell them to the final consumers. The grocery stores, supermarkets, 
shopping centers and ayurvedic shops are the major retailers prevalent in the market. Honey is packaged in plastic or glass jars of different weight, generally ranging from 100 grams to $1 \mathrm{~kg}$ and sold to the consumers.

\section{Consumers}

Consumers are the final value chain operators. The honey produced in the study area passes through different chain actors to reach on the hand of final consumers. There are two types of consumers who consume the honey produced in the study area. The first one is local consumers who buy crude or processed honey directly from producers and retailers shop. The second type of consumer is overseas consumers who buy exported honey.

\section{Value addition by different actors}

Table 3 reveals that the gross margin of beekeeper was Tk. 110 per $\mathrm{kg}$ honey. The marketing cost of beekeeper was Tk. 8 per $\mathrm{kg}$ honey. So, the value addition of beekeeper was Tk. 102 per kg. Likewise, the value addition of wholesaler, processor, commission agent, company and retailer were Tk. 90, Tk. 160, Tk. 40, Tk. 100 and Tk. 95, respectively. Total value addition by all the market actors was Tk. 587. Value addition was the highest by the processor which was $27.3 \%$. It was followed by beekeeper $(17.4 \%)$, company $(17 \%)$, retailer $(16.2 \%)$, wholesaler $(15.3 \%)$ and commission agent $(6.8 \%)$. The finding is similar with (Uddin et al., 2018) where the authors also found that value addition was the highest by the processor $(53.9 \%$ and $53.7 \%$ for pangas and tilapia, respectively). On the other hand, producers' share $(41.7 \%)$ was moderate which is considered as an indicator of increase in the efficiency of the marketing system in favor of the traders. It was also found that price spread Tk. 350 was very high which indicates the lower efficiency of the marketing system of honey.

\section{Livelihood status of beekeepers}

Engagement with different activities of beekeeping had a great impact on their livelihood. It is apparent from the table 4 that beekeepers' income was increased which improved overall socioeconomic condition and livelihood status. As the beekeepers were migratory, it is found that their self-managerial capability, social networking and efficiency were improved. Beekeepers affirmed that they have regular source of income from beekeeping and now are able to plan and buy inputs for other farming activities and paying school fees for their children. This means that their health condition, educational status, household stuff, etc. were enhanced though apiculture activities. Moreover, due to beekeeping, the least visible livelihood outcome was the pollination which tends to enhance crop yield and boost financial asset base. 
Table 3. Value addition of honey value chain actors

\begin{tabular}{|c|c|c|c|c|c|c|c|}
\hline \multirow[b]{2}{*}{ Particulars } & \multicolumn{7}{|c|}{ Market actors } \\
\hline & 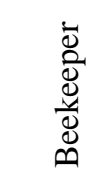 & 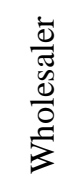 & 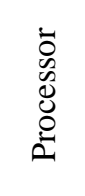 & 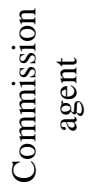 & $\begin{array}{l}\text { त्ञ } \\
\text { ڤ్ } \\
\text { ठ் }\end{array}$ & 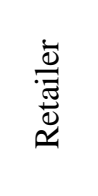 & 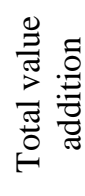 \\
\hline Production cost/ Purchase price (Tk./kg) & 140 & 200 & 210 & 225 & 250 & 500 & \\
\hline Marketing cost (Tk./kg) & 8 & 10 & 40 & 10 & 150 & 5 & \\
\hline Sales price $(\mathrm{Tk} . / \mathrm{kg})$ & 250 & 300 & 410 & 275 & 500 & 600 & \\
\hline Gross margin (Tk./kg) & 110 & 100 & 200 & 50 & 250 & 100 & \\
\hline Value addition (Tk./kg) & 102 & 90 & 160 & 40 & 100 & 95 & 587 \\
\hline$\%$ of total value addition & 17.4 & 15.3 & 27.3 & 6.8 & 17 & 16.2 & 100 \\
\hline \multicolumn{8}{|c|}{ Producers' share to consumers' } \\
\hline \multicolumn{6}{|l|}{ Producers' sale price (Tk./kg) } & \multicolumn{2}{|c|}{250} \\
\hline \multicolumn{6}{|l|}{ Consumers' purchase price (Tk./kg) } & \multicolumn{2}{|c|}{600} \\
\hline \multicolumn{6}{|l|}{ Price spread (Tk./kg) } & \multicolumn{2}{|c|}{350} \\
\hline \multicolumn{6}{|l|}{ Producers' share to consumers' Tk. (in \%) } & \multicolumn{2}{|c|}{41.7} \\
\hline
\end{tabular}

Table 4. Perceived livelihood status of beekeepers in the study area

\begin{tabular}{|c|c|c|c|c|c|c|c|}
\hline \multirow[t]{2}{*}{ Asset category } & \multicolumn{3}{|c|}{ Response } & \multirow{2}{*}{$\begin{array}{c}\text { Asset } \\
\text { category }\end{array}$} & \multicolumn{3}{|c|}{ Response } \\
\hline & Increase & Decrease & Constant & & Increase & Decrease & Constant \\
\hline \multicolumn{4}{|c|}{ Human capital } & \multicolumn{4}{|c|}{ Physical capital } \\
\hline Health & 77 & 3 & 20 & Building & 11 & 5 & 84 \\
\hline Education & 89 & 0 & 11 & Tin roof & 50 & 2 & 48 \\
\hline Training & 47 & 1 & 52 & Tube well & 35 & 0 & 65 \\
\hline Knowledge/ & 90 & 0 & 10 & Paka toilet & 27 & 0 & 73 \\
\hline Efficiency & & & & & & & \\
\hline \multirow{2}{*}{$\begin{array}{l}\text { Access to } \\
\text { information }\end{array}$} & 55 & 5 & 40 & Electric fan & 69 & 1 & 30 \\
\hline & \multicolumn{3}{|c|}{ Natural capital } & Motorcycle & 33 & 2 & 65 \\
\hline Cultivable land & 9 & 6 & 85 & Radio/TV & 72 & 0 & 28 \\
\hline $\begin{array}{l}\text { Using open water } \\
\text { resources }\end{array}$ & 0 & 0 & 100 & Chair/Table & 87 & 0 & 13 \\
\hline Forests & 0 & 0 & 100 & Mobile phone & 78 & 0 & 22 \\
\hline
\end{tabular}




\begin{tabular}{|c|c|c|c|c|c|c|c|}
\hline \multirow[t]{2}{*}{ Asset category } & \multicolumn{3}{|c|}{ Response } & \multirow{2}{*}{$\begin{array}{c}\text { Asset } \\
\text { category }\end{array}$} & \multicolumn{3}{|c|}{ Response } \\
\hline & Increase & Decrease & Constant & & Increase & Decrease & Constant \\
\hline & \multicolumn{3}{|c|}{ Social capital } & Shop & 12 & 1 & 87 \\
\hline $\begin{array}{l}\text { Involved in social } \\
\text { group }\end{array}$ & 49 & 8 & 43 & Refrigerator & 26 & 0 & 74 \\
\hline $\begin{array}{l}\text { Political } \\
\text { involvement }\end{array}$ & 67 & 4 & 29 & & \multicolumn{3}{|c|}{ Financial capital } \\
\hline $\begin{array}{l}\text { Self-managerial } \\
\text { capability }\end{array}$ & 86 & 2 & 12 & Cash in hand & 86 & 2 & 12 \\
\hline \multirow[t]{2}{*}{$\begin{array}{l}\text { Social } \\
\text { access/network }\end{array}$} & 70 & 9 & 21 & $\begin{array}{l}\text { Cash at bank/ } \\
\text { Liquid assets }\end{array}$ & 44 & 3 & 53 \\
\hline & & & & $\begin{array}{l}\text { Remittance/ } \\
\text { Donation }\end{array}$ & 2 & 1 & 97 \\
\hline
\end{tabular}

\section{SWOT analysis on honey value chain}

SWOT analysis on honey value chain reveals that the major strength was favorable environment for beekeeping (stated by $100 \%$ respondents). As major weakness, $95 \%$ respondents gave opinion about inadequate market infrastructure. The major opportunities included high demand in domestic market as well as international market (according to $100 \%$ respondents). All the respondents (100\%) identified dominancy of middleman in the market as serious threat (Table 5). The results are supported by (Bhandari and Kattel, 2020) where the authors identified favorable climatic conditions as the major strength, dominancy of traditional hives as the major weakness, high demand of unprocessed honey as the major opportunity and monocropping as the major threats of honey value chain in Nepal.

Table 5. SWOT analysis on honey value chain

\begin{tabular}{|c|c|c|c|}
\hline Strengths & $\begin{array}{l}\% \text { of } \\
\text { responses }\end{array}$ & Weakness & $\begin{array}{l}\% \text { of } \\
\text { responses }\end{array}$ \\
\hline $\begin{array}{l}\text { Honey has social acceptance as } \\
\text { food and medicinal product }\end{array}$ & 95 & $\begin{array}{l}\text { Lack of testing and quality } \\
\text { control facilities. }\end{array}$ & 70 \\
\hline $\begin{array}{l}\text { Favorable environment for } \\
\text { beekeeping }\end{array}$ & 100 & $\begin{array}{l}\text { Inadequate market } \\
\text { infrastructure }\end{array}$ & 95 \\
\hline $\begin{array}{l}\text { Bees can be helpful to increase } \\
\text { agricultural production through } \\
\text { pollination. }\end{array}$ & 90 & $\begin{array}{l}\text { Lack of access to financial } \\
\text { services }\end{array}$ & 90 \\
\hline $\begin{array}{l}\text { Availability of technical and } \\
\text { economic support from } \\
\text { government as well as non- } \\
\text { government organizations. }\end{array}$ & 50 & $\begin{array}{l}\text { Lack of knowledge about } \\
\text { colony size, stocking rate, } \\
\text { disease and pests. }\end{array}$ & 90 \\
\hline
\end{tabular}




\begin{tabular}{|c|c|c|c|}
\hline Strengths & $\begin{array}{l}\% \text { of } \\
\text { responses }\end{array}$ & Weakness & $\begin{array}{l}\% \text { of } \\
\text { responses }\end{array}$ \\
\hline Opportunities & $\begin{array}{l}\% \text { of } \\
\text { responses }\end{array}$ & Threats & $\begin{array}{l}\% \text { of } \\
\text { responses }\end{array}$ \\
\hline $\begin{array}{l}\text { High demand in domestic market } \\
\text { as well as international market }\end{array}$ & 100 & $\begin{array}{l}\text { Dominancy of middleman in } \\
\text { the market }\end{array}$ & 100 \\
\hline $\begin{array}{l}\text { Diversified business development } \\
\text { like wax, bee colony, queen and } \\
\text { beehives production }\end{array}$ & 90 & $\begin{array}{l}\text { Large number of retailers } \\
\text { who present themselves as } \\
\text { producer }\end{array}$ & 95 \\
\hline High employment opportunities & 70 & Traditional marketing system & 90 \\
\hline
\end{tabular}

Problems related to production, value addition and marketing of honey value chain

As shown in table 6 , most of the beekeepers commented that lack of credit, migration from one place to another and higher price of inputs were the major input and production related problems in apiculture activities. In response to product price/ marketing related problems, it is found that lower price at the honey flow season was the main constraint in beekeeping. Furthermore, lack of preservation and processing facilities were the main hindrance in case of value addition of honey value chain in the study areas. The present findings seem to be consistent with Goshme and Ayele (2020) where authors found that pests, disease and predators, shortage of bee forage, absconding, shortage of equipment, poor management practices were the constraints of honey production in Ethiopia.

Table 6. Ranking problems associated with honey value chain in the study area

\begin{tabular}{|c|c|c|c|c|c|c|}
\hline \multirow[b]{2}{*}{ Name of the problems } & \multicolumn{4}{|c|}{ Extent of problems } & \multirow[b]{2}{*}{ PFI } & \multirow{2}{*}{$\begin{array}{l}\text { Rank } \\
\text { order }\end{array}$} \\
\hline & $\begin{array}{l}\text { Severe } \\
\text { (3) }\end{array}$ & $\begin{array}{l}\text { Moderat } \\
\text { e (2) }\end{array}$ & $\begin{array}{c}\text { Low } \\
(1)\end{array}$ & $\begin{array}{c}\text { Not at all } \\
\quad(0)\end{array}$ & & \\
\hline \multicolumn{7}{|c|}{ Input and production related problems } \\
\hline Lack of credit & 58 & 3 & 0 & 0 & 180 & 1 \\
\hline Migration from one place to another & 55 & 4 & 2 & 0 & 175 & 2 \\
\hline Higher price of inputs & 50 & 6 & 4 & 1 & 166 & 3 \\
\hline Attack of pest and disease & 41 & 12 & 8 & 0 & 155 & 4 \\
\hline $\begin{array}{l}\text { Lack of scientific knowledge and } \\
\text { training }\end{array}$ & 37 & 10 & 9 & 5 & 140 & 5 \\
\hline $\begin{array}{l}\text { Ignorance of the farmers as bees are } \\
\text { harmful for crops }\end{array}$ & 33 & 15 & 9 & 4 & 138 & 6 \\
\hline \multicolumn{7}{|c|}{ Product price/ marketing related problems } \\
\hline
\end{tabular}




\begin{tabular}{|c|c|c|c|c|c|c|}
\hline \multirow[b]{2}{*}{ Name of the problems } & \multicolumn{4}{|c|}{ Extent of problems } & \multirow[b]{2}{*}{ PFI } & \multirow{2}{*}{$\begin{array}{l}\text { Rank } \\
\text { order }\end{array}$} \\
\hline & $\begin{array}{l}\text { Severe } \\
\text { (3) }\end{array}$ & $\begin{array}{l}\text { Moderat } \\
\text { e (2) }\end{array}$ & $\begin{array}{l}\text { Low } \\
(1)\end{array}$ & $\begin{array}{l}\text { Not at all } \\
\quad(0)\end{array}$ & & \\
\hline Lower price at the honey flow season & 59 & 9 & 4 & 0 & 199 & 1 \\
\hline Importation of honey & 57 & 8 & 6 & 1 & 193 & 2 \\
\hline Influences of powerful intermediaries & 48 & 16 & 7 & 1 & 183 & 3 \\
\hline \multicolumn{7}{|c|}{ Value addition and quality related problems } \\
\hline $\begin{array}{l}\text { Lack of preservation and processing } \\
\text { facilities }\end{array}$ & 56 & 14 & 2 & 0 & 198 & 1 \\
\hline $\begin{array}{l}\text { Inadequate skills in grading and } \\
\text { packaging }\end{array}$ & 38 & 21 & 9 & 4 & 165 & 2 \\
\hline $\begin{array}{l}\text { Lack of knowledge about byproduct of } \\
\text { honey }\end{array}$ & 46 & 12 & 2 & 12 & 164 & 3 \\
\hline
\end{tabular}

\section{CONCLUSION}

The study concludes that honey production has enormous opportunities to boost the livelihood enhancement of the stakeholders. Though Apis mellifera was found as the major honey bee reared by the beekeepers, the honey production could be expanded with more rearing to other bee species at large scale. The study exposed that processors added the highest value of total value addition among the value chain actors involved in honey value chain. Lack of credit, lower price of honey at the honey flow season, and lack of preservation and processing facilities were the main problems for value chain of honey. Considering the findings of the study, some essential policy recommendations have been arisen which are: contract based cooperative groups should be established, proper preservation and processing facilities should be ensured. Moreover, government and non-government organizations should provide scientific and technical assistance to encourage chain actors in order to develop honey farming as a commercial venture.

\section{ACKNOWLEDGEMENT}

The authors express gratefulness to Bangladesh Agricultural University Research System (BAURES) for funding to conduct this research.

\section{REFERENCES}

Acharya, S.S. and Agarwal, N.L. (1987). Agricultural Marketing in India, Oxford and IBH Publishing Co. Pvt. Ltd. 66, Janpath, New Delhi.

Amin, M.R., Nishat, M.J.A. and Ghosh, P. (2019). Apiculture for sustainable agriculture: Bangladesh perspective. Bangladesh Journal of Ecology, 1(1): 47-52. 
BBS. (2018). The Yearbook of Agricultural Statistics, Ministry of Planning, Government of the People's Republic of Bangladesh, Dhaka.

BBS. (2016). Household Income and Expenditure Survey, Ministry of Planning, Government of the People's Republic of Bangladesh, Dhaka.

Bhandari, P.L. and Kattel, R.R. (2020). Value chain analysis of honey sub-sector in Nepal. International Journal of Applied Science Biotechnology, 8(1): 83-95.

Bhattarai, S., Pandey, S.R., Bhattarai, S.K., Karn, R., Gurung, S., Chapain, A., Bhatta, S. and Dutta, J.P. (2020). Value chain analysis of honey bee (Apis mellifera) products in Chitwan, Nepal. Azarian Journal of Agriculture, 7(1): 26-35.

DFID. (2000). Livelihood assessment of communities and households and technical assistance of aquaculture technologies and methods, Department for International Development, Dhaka.

Dillon, J.L. and Hardekar, J.B. (1993). Farm management research for small farmers' development. Food and Agricultural Organization of the United Nations, Rome, Italy.

Furuholt, B. and Matotay, E. (2011). The developmental contribution from mobile phones across the agricultural value chain in rural Africa. The Electronic Journal of Information Systems in Developing Countries, 48(1): 1-16.

Goshme, D. and Ayele, T. (2020). Constraints of honey production and marketing in Ethiopia: A review. Agricultural Reviews, 41(4): 393-397.

Goswami, A. (2016). Financial profitability and value chain analysis of pangas in a selected area of Mymensingh district. Master of Science Thesis, Department of Agricultural Economics, Bangladesh Agricultural University, Mymensingh.

Gujarati, D.N. (2003). Basic Econometrics. $4^{\text {th }}$ edition, McGraw-Hill, New York. Pp. 553-555.

ICIMOD. (2015). Sustainable livelihoods in the Kailash sacred landscape: promotion of the chyura honey value chain in India. International Centre for Integrated Mountain Development, Kathmandu, Nepal.

Islam, M.R., Chhay, L., Mian, M.M. and Nasry, A.A.N.B. (2015). The financial analysis of apiculture profitability in Bangladesh. Asian Journal of Agricultural Extension, Economics and Sociology, 9(2): 1-8.

Kaplinsky, R. and Morris, M. (2001). A handbook for value chain research. International Development Research Centre, Ottawa, Canada.

Klein, A.M., Vaissiere, B.E., Cane, J.H., Ingolf, S.D., Cunningham, S.A., Kremen, C. and Tscharntke, T. (2007). Importance of pollinators in changing landscapes for world crops. Proceedings of the Royal Society B. Biological Sciences, 274(1608): 303-313.

Moniruzzaman, M. and Rahman, M.S. (2009). Prospects of beekeeping in Bangladesh. Journal of Bangladesh Agricultural University, 7(1): 109-116.

Mujuni, A., Natukunda, K. and Kugonza, D.R. (2012). Factors affecting the adoption of beekeeping and associated technologies in Bushenyi district, Western Uganda. Livestock Research for Rural Development, 24 (8): 133.

Shrestha, S., Pandey, B. and Mishra, B.P. (2017). Honey value chain analysis - a case study of Gahate village, Lamjung district of Nepal. International Journal of Multidisciplinary Research and Development, 4(6): 107-112. 
Uddin, M.T., Islam, M.M. and Nasrin, M. (2018). A study on value added dairy products and availability of milk, meat and egg at consumers' level in selected areas of Bangladesh. Bangladesh Journal of Livestock Research, 21-25: 45-55.

Uddin, M.T., Goswami, A., Rahman, M.S., Dhar, A.R. and Khan, M.A. (2018). Value chain of pangas and tilapia in Bangladesh. Journal of Bangladesh Agricultural University, 16(3): 503-512.

Verma, L.R. (1990). Apiculture in Bhutan: Problems and Prospects. In: Honey Bee in Mountain Agriculture, L. R. Verma. West View Press, Boulder, San Francisco, Oxford. Pp.164-179. 